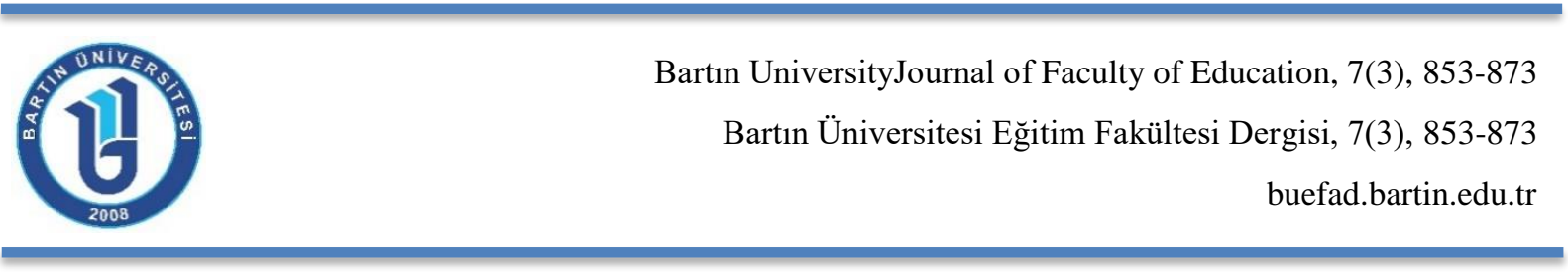

\title{
Happiness as a Predictor of Attitude towards Teaching Profession: Pedagogical Formation Case
}

\author{
Akif KÖSE*a, Abdullah ÇEVIKK
}

\begin{tabular}{l} 
Article Info \\
\hline DOI: $10.14686 /$ buefad.393207 \\
\hline Article History: \\
Received $\quad 10.02 .2018$ \\
Accepted $\quad 30.09 .2018$ \\
Published $\quad 31.10 .2018$ \\
\hline Keywords: \\
Pedagogical Formation \\
Happiness \\
Attitude \\
\hline Article Type: \\
Research Article
\end{tabular}

\begin{abstract}
This research aims to identify the relationship between prospective teachers' happiness levels and their attitudes towards teaching profession. This is a quantitative study conducted in a relational survey model. The research sample consists of 338 students receiving pedagogical formation education at Kahramanmaraş Sütçü İmam University Faculty of Education during the spring semester of 2015 and 2016 academic year. The research has employed Oxford Happiness Questionnaire Short Form and Teacher Profession Attitude Scale. Research results have revealed a positive and significant relationship between pedagogical formation students' happiness levels and their attitudes towards teaching profession. There exists a significant difference between the happiness levels of the pedagogical formation students and their attitudes towards teaching profession in terms of marital status. The happiness levels of the single students and their attitudes towards teaching profession have been found to be much more positive compared to those who are married. Another result of the research shows that a part of the students' attitudes are explained by their happiness levels.
\end{abstract}

\section{Öğretmenlik Mesleğine Yönelik Tutumun Bir Yordayıcısı Olarak Mutluluk: Pedagojik Formasyon Örneği}

\begin{tabular}{|c|c|}
\hline \multicolumn{2}{|c|}{ MakaleBilgisi } \\
\hline \multicolumn{2}{|c|}{ DOI: 10.14686/buefad.393207 } \\
\hline \multicolumn{2}{|c|}{ MakaleGeçmişi: } \\
\hline Geliș & 10.02 .2018 \\
\hline Kabul & 30.09 .2018 \\
\hline Yayın & 31.10 .2018 \\
\hline \multicolumn{2}{|c|}{$\begin{array}{l}\text { AnahtarKelimeler: } \\
\text { Pedagojik Formasyon } \\
\text { Mutluluk } \\
\text { Tutum }\end{array}$} \\
\hline \multicolumn{2}{|c|}{$\begin{array}{l}\text { MakaleTürü: } \\
\text { Araştırma Makalesi }\end{array}$} \\
\hline
\end{tabular}

\begin{abstract}
Öz
$\mathrm{Bu}$ çalışmada pedagojik formasyon eğitimi alan öğrencilerin mutluluk düzeyleri ile öğretmenlik mesleğine yönelik tutumları arasındaki ilişkinin incelenmesi amaçlanmıştır. Araştırma nicel bir çalışma olup ilişkisel tarama modelinde gerçekleştirilmiştir. Araştırmanın örneklemini 2015-2016 eğitim öğretim yılında Kahramanmaraş Sütçü İmam Üniversitesi Eğitim Fakültesinde pedagojik formasyon eğitimi alan 338 öğrenci oluşturmaktadır. Araştırmada veri toplama aracı olarak Oxford Mutluluk Ölçeği ve Öğretmenlik Mesleğine Yönelik Tutum Ölçeği kullanılmıştır. Araştırma sonucunda pedagojik formasyon öğrencilerinin mutluluk düzeyleri ile ögretmenlik mesleğine yönelik tutumları arasında pozitif yönde anlamlı bir ilişkinin olduğu görülmüştür. Ayrıca öğrencilerin mutluluk düzeyleri ve öğretmenlik mesleğine yönelik tutumlarının medeni durumlarına göre anlamlı düzeyde farklılaştığı ortaya çıkmıştır. Bekâr öğrencilerin mutluluk düzeylerinin evli öğrencilere göre daha yüksek olduğu, öğretmenlik mesleğine yönelik tutumlarının ise evli öğrencilere göre daha olumlu olduğu görülmüştür. Öğretmenlik mesleğine yönelik tutumun bir kısmının öğrencilerin mutluluk durumları ile açıklandığı, bir diğer sonuç olarak ortaya çıkmıştır.
\end{abstract}

\footnotetext{
*Corresponding Author: akifkose @ ksu.edu.tr

${ }^{a}$ Lecturer Dr., Kahramanmaraş Sütçü İmam University, Kahramanmaraş/Turkey, http://orcid.org/0000-0002-6961-6052) ${ }^{\text {b}}$ Teacher, Kahramanmaraş Provincial Directorate of National Education, Kahramanmaraş/Turkey, http://orcid.org/00000003-0659-480X)
} 


\section{Introduction}

The main aim of the education systems is to educate qualified work force and to raise citizenship awareness (Temizkan, 2008). Qualified teachers are also needed so that qualified work force can be trained. Because the quality of the new generations will no doubt be the same with the qualities of the teachers (Çelikten, Şanal \& Yeni, 2005). The most significant factor in fulfilling the values that the public expects from education is the teacher factor (Azar, 2011). In this regard, teaching is a profession that is regarded as sacred by society and has a prestigious place.

Countries commit their future to teachers and build the bases with today's teachers. Teachers are indispensable elements of the education systems. Scientific and technological advances in the world facilitate learning. However, no matter how these advances offer opportunities that facilitate learning, the concept of teacher always maintains its position as the first element that cannot be substituted in education and training (Can, 2010).

Teachers' well-being is of great importance in terms of achieving educational objectives because they have a considerable influence on educational systems. One of the indicators of this psychological well-being is the happiness and the levels of the happiness since there is a close relationship between happiness and life quality of an individual (Kangal, 2013). It is probable that happiness will provide a quality work life for teachers; otherwise it will present an unqualified working life at a rate that will vary across the level of unhappiness (Demir, 2017). In this regard, whether teachers are happy or not can be considered as an important factor affecting the quality of education. The significance of the happiness in terms of the working style and private life of the teachers opens a new gate for examining the happiness levels of the pedagogical formation students who are regarded as prospective teachers and determining the effect of pedagogical formation students' happiness levels on their attitudes towards teaching profession.

\section{Happiness}

Happiness has attracted the attention of people since the early ages, and various researches have been carried out in this regard (Doğan, Sapmaz \& Çötok Akıncı, 2013). Happiness is a concept that physiologically, psychologically, cognitively, socially and religiously etc. surrounds humans (Demir, 2017). People have tried to interpret and understand happiness in terms of their location, time, culture, philosophical or religious belief. Those who are happy are much more cheerful, hopeful, and take more pleasure in everything they do compared to the other people (Tingaz, 2013).

Happiness is the mood that man possesses as he obtains his wishes and expectations (Duran, 2016). Farabi thinks that happiness is such an aim that it can be attained through virtuous actions, and the opposite is misfortune. There is nothing more than that an individual can achieve beyond happiness (Özgen, 1997). Descartes defines happiness as full soul satisfaction and pleasure (Aydoğan, 2015). Happiness is the competency that enables man to realize his own potential powers, to do his homework, to be virtuous, to live in harmony with the laws of nature, and to determine freely his own destiny (Cevizci, 2003). Happiness is a positive emotion involving a whole series of pleasures that are long-held and delightful (Franklin, 2010). Happiness in an objective sense that refers to good living conditions, peace, tranquility and freedom, while in a subjective sense, happiness is a mental state that expresses temporary emotions (Veenhoven, 2000: as cited in Yalçın, 2016). The term of happiness is defined as "subjective well-being" in psychology (Eryılmaz, 2011). Subjective well-being means that individuals frequently experience positive emotions, and rarely have negative emotions and they have high subjective well-being (Hybron, 2000).

Happiness that mankind has been seeking for centuries has become a more needed concept as a result of the adverse effects brought about by changing conditions today (Baysal \& Aka, 2013). According to Freud, the way of meeting this need goes through the satisfaction of the instinctive desires of the people (Froom, 1995). Russel (2003) notes that our happiness depends on extending our interests and hopes as much as possible. There are two ways to capture your happiness. The first is that the individual is aware of himself, and the second is the communication with the people (Tarhan, 2013).

Various classifications are available related to happiness. However, basically, two general perspectives of happiness come to the forefront in the relevant literature. The first is the hedonic happiness approach which focuses on feelings and is expressed as the total achievements of pleasure attainment and pain avoidance. Eudaimonic 
happiness is related to virtues and values. This approach notes that happiness, virtue and values make life meaningful. (Ryan \& Deci, 2001).

\section{Attitude}

The aim of contemporary education systems is to educate individuals who have advanced problem-solving skills, who know how to achieve knowledge, who think analytically, and who keep the desire for acquiring knowledge alive (Akpınar, Y1ldı, \& Ergin, 2006). Achieving these goals depends to a great extent upon the quality and competencies of the teachers. Teaching profession is a professionally occupied field that have social, cultural, economic, scientific and technological dimensions and that requires special expertise knowledge and skill along with professional formation (Erden, 1998). The teaching profession requires patience, dedication and continuous work. It is necessary to perform this profession lovingly and willingly in order to successfully fulfill the teaching profession (Çapa\&Çil, 2000). This is possible only when the teacher develops a positive attitude towards the profession.

The attitude, the central part of the individuality (Bohner \& Wanke, 2002), is the permanent organization of the instinctive, emotional, perceptual and mental processes of an individual in his/her life (Krech \& Grutchfield, 1965; as cited in Temizkan, 2008). Attitudes are based on beliefs and value judgments and sustain their existence over these phenomena (Çiçek Sağlam, 2008). The attitude towards any profession is the determinant of how one conducts that profession (Şenel, Demir, Sertelin, Kılıçaslan, \& Köksal, 2004). In this respect, the attitude towards the teaching profession is likely to be directly related to the quality of education.

It is essential to determine the attitudes of prospective teachers towards the profession and to transform negative attitudes into positive in order to train qualified teachers and increase the success of the teacher training program (Semerci \& Semerci, 2004). Prospective teachers' perceptions in their fields and possessing positive attitudes towards the teaching profession are the reflections of how they will perceive their professions in the future (Şahin, Zade, \& Direk, 2009). The personality of the teacher, professional competency and attitude towards the teaching profession are of vital importance (Alın \& Bekdemir, 2006). Because the positive aspects of teachers' perspectives towards the profession will make them more self-sacrificing and more effective when they start performing their profession (Erdem, Gezer, \& Çokadar, 2005).

An increase in prospective teachers' positive attitudes towards the teaching profession will enable them to fulfill their responsibilities, to understand the new educational model of the educational institutions, to question learning theories, pedagogical methods and training programs, and to develop redesign skills (Akkaya, 2009). Teachers' attitudes towards their professions are also of utmost importance in fulfilling their teaching profession more fondly and more successfully (Çiçek Sağlam, 2008). Teachers' attitudes especially towards their profession, students and school studies have a wide effect on the learning and personality of the students (Küçükahmet, 2003). A positive attitude towards the teaching profession will positively affect all elements related to the teacher (Baykara Pehlivan, 2008). For this reason, the training of prospective teachers with a positive professional attitude will contribute to their fulfillment of their duties more thoroughly after starting to work, to show positive behaviors towards their students, to be researchers and creative thinkers and to transfer the innovations in the field to learning environments (Temizkan, 2008).

The existence of a positive professional attitude with such an important place in terms of the teaching profession does not simply depend upon a reason, a situation or a variable. It can be stated that many variables are influential on the prospective teachers' positive attitude toward the teaching profession (Usta \& Korkmaz, 2010), and the existence, absence, quantity and quality of the positive attitude are all related to these variables. Knowing the attitudes of prospective teachers towards the profession makes it possible to make the necessary evaluations. In line with the evaluations, the quality of education may be improved with the steps in order to develop a positive professional attitude. This contribution may be said to be important in terms of the education system. Hence, this study has concentrated on whether there is a relation between prospective teachers' happiness levels and their attitudes towards teaching profession, and if so what is the direction and level of this relationship; whether happiness affects the attitude towards the teaching profession or not. This research is expected to contribute to the field in this regard. Therefore, this research aims to identify "the relationship between prospective teachers' happiness levels and their attitudes towards teaching profession”. In service of this goal, answers to the following questions have been sought:

1. What are the happiness levels of pedagogical formation students? 
2. Do the happiness levels of pedagogical formation students vary across some demographic variables?

3. What are the attitude levels of pedagogical formation students towards the teaching profession?

4. Do the attitudes of pedagogical formation students towards the teaching profession differ depending on some demographic variables?

5. Is there a significant relationship between the happiness levels of pedagogical formation students and their attitudes towards teaching profession? If any, what is the direction and level of the relationship?

6. To what extent do pedagogical formation students' happiness levels predict their attitudes towards the teaching profession?

\section{Method}

This section includes research design, population and sample, data collection tools and data analysis.

\section{Research Design}

This is a quantitative study conducted in a relational survey model. Relational survey models are those which aim to determine the relationships between variables or to determine the existence and/or degree of changes between two or more variables (Karasar, 2016). This research aims to determine the direction and level of the correlation between happiness and teaching attitude variables and identify to what extent the level of happiness predicts attitude towards teaching profession.

\section{Population and Sampling}

The population of the research consisted of 344 students receiving pedagogical formation education at Sütçü İmam University Faculty of Education during the spring semester of 2015-2016 academic year. The whole research population has been determined as research sample and 338 research data have been obtained in total. Demographic characteristics of the participants are presented in Table 1.

Tablo 1: The Demographic Characteristics Regarding Participants

\begin{tabular}{|c|c|c|c|c|c|c|c|c|c|}
\hline $\begin{array}{l}\text { Demographic } \\
\text { Characteristics }\end{array}$ & Male & Female & Married & Single & Graduated & Student & $\begin{array}{l}20-25 \\
\text { Age }\end{array}$ & $\begin{array}{l}26-29 \\
\text { Age }\end{array}$ & $\begin{array}{l}29 \text { Years } \\
\text { and } \\
\text { Older }\end{array}$ \\
\hline Gender & $\begin{array}{l}140 \\
(\% 41,4)\end{array}$ & $\begin{array}{l}198 \\
(\% 58,6)\end{array}$ & & & & & & & \\
\hline Marital Status & & & $\begin{array}{l}64 \\
(\% 19)\end{array}$ & $\begin{array}{l}274 \\
(\% 81)\end{array}$ & & & & & \\
\hline $\begin{array}{l}\text { Graduation } \\
\text { Status }\end{array}$ & & & & & $79(\% 23,3)$ & $\begin{array}{l}259 \\
(\% 76,7)\end{array}$ & & & \\
\hline Age & & & & & & & $\begin{array}{l}75 \\
(\% 22,2)\end{array}$ & $\begin{array}{l}164 \\
(\% 48,5)\end{array}$ & $\begin{array}{l}99 \\
(\% 29,3)\end{array}$ \\
\hline
\end{tabular}

\section{Data Collection Tools}

The first part of the data collection tool includes demographic variables such as gender, marital status and education status of the participants. The second part includes the scale used for determining the happiness levels of the pedagogical formation students and the last part holds the one used for identifying the teaching attitudes of the pedagogical formation students.

With the goal of determining pedagogical formation students' happiness levels, the study employed the Oxford Happiness Questionnaire Short Form, which was developed by Hills and Argyle in 2002. This scale, which was adapted to Turkish by Doğan and Çötok (2011), possesses one factor and 7 items. The internal consistency coefficient was found to be 0.85 for the overall scale. In this study, the reliability coefficient was determined to be .70 . 
The "Teacher Profession Attitude Scale" developed by Bulut (2011) and tested for validity and reliability by Atalmış (2016) was formed in order to determine students' attitudes towards teaching profession. The tool includes 4 factors-"Priority, Qualification, Negativity and Willingness"- and 20 items. The internal consistency coefficient was identified to be 0.81 for the overall scale. For the factors - priority, qualification, negativity and willingnessthe coefficients were determined to be $0.57,0.55,0.56$ and 0.71 , respectively. The Cronbach's alpha coefficient of the total scale was found to be 0.85 in the current study. When it comes to the reliability coefficients of the factors, it is ". 57 " for priority, ".61" for qualification, ".58" for negativity and ".83" for willingness.

The responses to the scales were rated as five-point Likert type. With a view to determining the level of fulfillment of each item in the data collection tools, the rating was used as "Totally agree (5)", "Agree (4)", "Partially agree (3)", "Disagree (2)", and "Totally Disagree (1)". The score intervals were determined as 1.00-1.80 "Totally Disagree"; 1.81-2.60 "Disagree"; 2.61-3.40 "Partially agree", 3.41-4.20 "Agree"; 4.21-5.00 "Totally agree".

\section{Data Analysis}

The research data regarding pedagogical formation students' happiness levels and their attitudes towards teaching profession were analyzed using SPSS for Windows 21.0. Mean and standard deviation values were calculated during data analysis. The normality test was assessed to test whether the data were distributed normally. As a result of the analyses, the data demonstrated normal distribution.

Table 2. The Results of Normality Test

\begin{tabular}{llllll}
\hline \multirow{2}{*}{ Variables } & $\mathbf{N}$ & \multicolumn{3}{c}{ Skewness } & Kurtosis \\
\cline { 3 - 6 } & & Statistic & Std. Error & Statistic & Std. Error \\
\hline Happiness & 338 &,- 392 &, 133 &, 172 &, 265 \\
Attitude & 338 &,- 864 &, 133 &, 827 &, 265 \\
\hline
\end{tabular}

Table 2 displays that skewness values are between -1 and +1 which reveals that the data is normally distributed. Thus, $t$ test was used in order to determine whether happiness and attitude differ across several demographic characteristics. Correlation (r) and regression analysis were performed in correlational calculations.

\section{Findings}

This section of the study contains research findings. The order of the findings is the same with the order of research questions.

\section{Findings Related to Pedagogical Formation Students' Happiness Levels and Their Attitudes towards Teaching Profession}

Table 3 shows the mean values and standard deviations of the pedagogical formation students' levels of happiness and their attitudes towards the teaching profession and their sub-dimensions.

Table 3. Mean and Standard Deviation Values regarding the Pedagogical Formation Students' Happiness Levels and Their Attitudes towards Teaching Profession

\begin{tabular}{lccc}
\hline Tools & $\mathbf{n}$ & $\overline{\mathbf{x}}$ & $\mathbf{S}$ \\
\hline Happiness & 338 & 2,96 & 1,07 \\
\hline Attitude towards Teaching Profession & 338 & 3,86 &, 915 \\
Priority & 338 & 4,31 &, 856 \\
Negativity & 338 & 3,13 & 1,19 \\
Qualification & 338 & 4,56 &, 690 \\
Willingness & 338 & 4,01 &, 983 \\
\hline
\end{tabular}


As indicated in Table 3, the happiness levels of pedagogical formation students have been identified as "slightly agree" ( $\bar{x}=2,96)$, while their attitudes towards teaching profession is at the level of "agree" ( $\bar{x}=3,86)$. Accordingly, students have medium level of happiness, and they have a positive attitude towards teaching profession.

2. Analysis of Pedagogical Formation Students' Happiness Levels and Their Attitudes towards Teaching Profession in terms of Several Variables

Table 4 presents pedagogical formation students' happiness levels and their attitudes towards teaching profession in terms of several variables.

Table 4.-Difference of Pedagogical Formation Students' Happiness Levels and Their Attitudes towards Teaching Profession in terms of Several Demographic Characteristics

\begin{tabular}{|c|c|c|c|c|c|c|c|c|c|}
\hline \multirow{2}{*}{ Variables } & & \multicolumn{2}{|c|}{ Gender } & \multicolumn{2}{|c|}{ Marital Status } & \multicolumn{2}{|c|}{$\begin{array}{c}\text { Graduation } \\
\text { Status }\end{array}$} & \multicolumn{2}{|c|}{ Age } \\
\hline & & $\mathbf{t}$ & $\mathbf{p}$ & $\mathbf{t}$ & $\mathbf{p}$ & $\mathbf{t}$ & $\mathbf{p}$ & $\mathbf{F}$ & $\mathbf{p}$ \\
\hline Happiness & & $-1,641$ & ,101 & $-2,625$ &, $009^{*}$ & 1,591 & ,113 & 1,591 &, 113 \\
\hline $\begin{array}{l}\text { Attitude towards } \\
\text { Profession }\end{array}$ & Teaching & $-1,499$ & ,135 & $-2,293$ &, $022^{*}$ & 1,300 & ,195 & 1,300 & , 195 \\
\hline Priority & & $-1,174$ &, 241 & $-2,054$ &, $041^{*}$ & ,575 &, 566 &, 575 & ,566 \\
\hline Negativity & &,- 839 & ,402 &,- 764 & ,445 & 1,620 &, 106 & 1,620 & , 106 \\
\hline Qualification & & $-1,763$ & ,079 & $-1,954$ &, 052 & 1,755 & ,080 & 1,755 & ,080 \\
\hline Willingness & &,- 759 & ,449 & $-2,366$ &, $019^{*}$ & ,819 & ,413 & ,819 & ,413 \\
\hline
\end{tabular}

$* \mathrm{p}<.05$

Upon analyzing the findings in Table 4, no significant difference has been noted across pedagogical formation students' happiness levels in terms of gender. Accordingly, it may be stated that students' gender does not have an effect on their happiness levels. A statistically significant difference has been identified between pedagogical formation students' happiness levels in terms of their marital status $\left[\mathrm{t}_{(342)}=-2,625, \mathrm{p}<, 05\right]$. Considering the average of the rankings, the difference has been found in favour of those who are single $\left(\overline{\mathbf{X}}_{\text {Married }}=3,51 ; \overline{\mathbf{X}}_{\text {Single }}=3,66\right)$. The fact that single students are happier compared to the married may result from various factors such as having fewer responsibilities, economically supported by scholarships and /or their families as well as being much freer than married students. In addition, pedagogical formation students' happiness levels do not significantly differ in terms of their graduation status and ages.

Table 4 shows no significant difference between pedagogical formation students' attitudes towards the teaching profession in terms of gender. Both male and female students have high levels of attitudes towards teaching

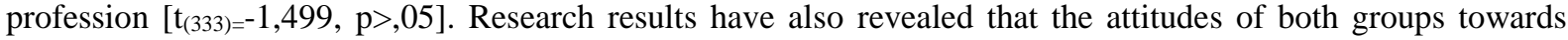
teaching profession are at "I agree" level $\left(\overline{\mathrm{X}}_{\text {Male }}=4,06 ; \overline{\mathrm{X}}_{\mathrm{Female}}=4,14\right)$.Besides, the attitudes of the prospective teachers towards the profession and the sub-dimensions do not significantly differ across their graduation status and ages

A statistically significant difference has been noted across the participants' views on their attitudes towards the teaching profession in terms of their marital status $\left[\mathrm{t}_{(336)}=-2,293, \mathrm{p}<, 05\right]$. Thus, single students have been determined to have more positive attitudes towards teaching profession compared to those who are married $\left(\overline{\mathbf{X}}_{\text {Married }}\right.$ $\left.=4,08 ; \overline{\mathbf{X}}_{\text {Single }}=4,23\right)$. As for the students' graduation status, no significant difference has been found between their attitudes towards teaching profession. When the attitudes towards the teaching profession have been analyzed, a significant difference has been identified in the priority subscale in favor of those who are single $\left(\overline{\mathrm{X}}_{\text {Married }}=4,28\right.$; $\left.\overline{\mathbf{X}}_{\text {Single }}=4,47\right)$; a similar result has emerged in terms of participants' marital status $\left(\overline{\mathbf{X}}_{\text {Married }}=2,38 ; \overline{\mathbf{X}}_{\text {Single }}=2,52\right)$.

Table 4 also suggests that there is no significant difference between the ages of pedagogical formation students and their attitudes towards teaching profession. There is also no significant difference in the sub-dimensions of attitudes towards the teaching profession. 
3. Findings Regarding the Relationship between the Pedagogical Formation Students' Happiness Levels and Their Attitudes towards Teaching Profession

Table 5 displays the Pearson correlation analysis conducted so as to identify the relation between the happiness levels of pedagogical formation students and their attitudes towards teaching profession.

Table 5. Relationship between Pedagogical Formation Students' Happiness Levels and Their Attitudes towards Teaching Profession

\begin{tabular}{lll}
\hline Happiness & Happiness & Attitude \\
$\mathrm{p}$ & 1 & \\
Attitude &, $223^{*}$ & 1 \\
$\mathrm{p}$ &, 000 & \\
$* \mathrm{P}<0,01$ &
\end{tabular}

A low, positive and significant relationship has been found between pedagogical formation students' happiness levels and their attitudes towards teaching profession. It can be mentioned that as the happiness levels of the students increase, their attitudes towards the teaching profession also increase.

\section{The Effect of Pedagogical Formation Students' Happiness Levels on Their Attitudes towards Teaching Profession}

The results of the regression analysis used to determine whether pedagogical formation students' happiness levels predict their attitudes towards teaching profession are presented in Table 6.

Table 6. The Results of Regression Analysis regarding the Effect of Pedagogical Formation Students' Happiness Levels on Their Attitudes towards the Teaching Profession

\begin{tabular}{llllllll}
\hline $\begin{array}{l}\text { Dependent } \\
\text { Variable }\end{array}$ & $\begin{array}{l}\text { Independent } \\
\text { Variable }\end{array}$ & $\mathbf{B}$ & SE & $\boldsymbol{\beta}$ & T & $\mathbf{p}$ & $\begin{array}{l}\text { Durbin } \\
\text { Watson }\end{array}$ \\
\hline Happiness & Constant & 69,868 & 2,848 & & 24,534 &, 000 & 2,12 \\
& Attitude &, 505 &, 115 &, 233 & 4,392 &, 000 & \\
\hline $\mathrm{R}=, 233$ & $\mathrm{R}^{2}=, 054 \quad \mathrm{~F}=19,289$ & $\mathrm{P}=, 000$ & & & & &
\end{tabular}

Table 6 depicts that the Durbin Watson value of the regression model is 2.12. It can also be stated that the value of 2.12 is acceptable for the regression model considering that the Durbin Watson test, which indicates whether there is a correlation between the error terms, points out that there is no correlation between error terms of the statistical value of 2 and this is valid regarding the regression analysis. In addition, Table 6 also suggests that 5\% of the total variance of the pedagogical formation students' attitudes towards the teaching profession is explained by the happiness variable, and students' happiness levels significantly affect their attitudes towards the teaching profession positively.

\section{Conclusion, Discussion and Recommendations}

Research results have revealed that pedagogical formation students' happiness level is medium in general. Because the high scores obtained from the scale of happiness reveals that the level of happiness of the individual increases (Doğan and Sapmaz, 2012). Given the lowest score that can be taken from the scale is 7 and the highest score is 35, it can be stated that pedagogical formation students having 20 score in total have a medium level of happiness. The study conducted by Yazic1 (2015) is also in line with the result of this study. In another study conducted with university students, the happiness levels of the students have been found to be high (Aksoy, Güngör Aytar \& Kaytez, 2016). The reason for pedagogical formation students not to have high happiness levels may result from the fact that they continue both undergraduate education and pedagogical formation education in the same breath. The fact that most pedagogical formation students who have completed their undergraduate education have not had a job yet, and those who have jobs run their business and educational lives at the same time may be considered as the probable reasons for their low happiness levels. 
Another result of the research is the high level of the attitudes of the pedagogical formation students towards the teaching profession. Similar results have emerged in studies conducted by Kaya and Büyükkasap (2005), Gürbüz and Kışoğlu (2007), Doğan and Çoban (2009) and Can (2010). One such study carried out by Yildız and Ergin (2006) revealed that prospective science teachers' attitudes toward the teaching profession are at medium level. One of the variables determining the attitude towards the teaching profession is education (Bursalıoglu, 2012). Therefore, the pedagogical formation education may lead to the increase in the positive attitude of the students towards the teaching profession.

Besides, no significant difference has been identified across pedagogical formation education students' happiness levels in terms of gender. The findings of the studies conducted by Gönener, Öztürk and Y1lmaz (2017), Aksoy, Güngör and Kaytez (2017) and Akyüz, Yaşartürk, Aydın, Zorba and Türkmen (2017) are in line with those of the current study. They have found no significant difference between happiness levels in terms of gender. However, a significant difference has been found between young adults' happiness levels in terms of gender (Gülcan \& Nedim Bal, 2014). According to the understanding of meaningful happiness, virtue and values give meaning to life and this means happiness (Ryan \& Deci, 2001). It can be stated that the happiness levels of different samples may differ across gender as the virtues and values that people have and the difference level of experience are the determinants of the happiness levels of individuals.

Research results have suggested that pedagogical formation students' attitudes towards the teaching profession do not significantly differ in terms of gender. This finding is in line with those of Özdere, Konedralı and Perkan Zeki (2010) and Demirtaş, Cömert and Özer (2011). On the other hand, in studies conducted by Çapa and Çil (2000) and Baykara Pehlivan (2008), significant differences have been identified across prospective teachers' attitudes towards teaching profession depending on gender.

There exists a significant difference between the happiness levels of the pedagogical formation students in terms of their marital status. Single students are happier compared to those who are married. Similar results have been observed in the studies conducted by Şentürk (2011) and Cihangir (2005). Still, Habibzadeh and Allahvirdiyani (2011) have concluded that there is no significant difference between happiness and marital status. As a result of this research, the finding that single students are happier than married students can be explained by the relatively low responsibilities of single students compared to married students.

As a result of the research, a significant difference has been noted among students' attitudes towards the teaching profession in terms of their marital status. Single students' attitudes towards the teaching profession are more positive than married students. Attitude organizes the mental processes permanently, emotionally and instinctively against the events of the individual's life (Krech \& Grutchfield, 1965: as cited in Temizkan, 2008). The fact that the single students are mostly younger than the married ones and they have less mental disruption accounts for the fact that their attitudes towards the teaching profession are more positive than the married ones. Moreover, pedagogical formation students' happiness levels and their attitudes towards teaching profession do not significantly vary across their graduation status and ages.

The results of the current research have demonstrated that there is a low positive correlation between the pedagogical formation students' happiness levels and their attitudes towards the teaching profession. The happiness levels of the students have been indicated to be a significant predictor of their attitudes towards the teaching profession. Establishing environments that increase the happiness levels of pedagogical formation students will also increase their positive attitudes toward the teaching profession. Indeed, previous researches suggest that the high attitudes of teachers towards their professions make it easier for them to become more qualified and effective teachers (Çiçek Sağlam, 2008; Erdem, Gezer \&Çokadar, 2005). Thus, if education faculties and other faculties providing training for pedagogical formation devote more place and time to the activities that enhance students' attitudes towards the teaching profession, it will positively influence prospective teachers' attitudes towards the teaching profession, thereby contributing to the quality of the education system.

Based upon the research findings, the following recommendations have been provided:

\section{Recommendations Based upon the Research Findings}

1.1. Research findings have revealed that the increase in the happiness levels of the students leads to a positive influence on their attitudes towards the teaching profession. Therefore, social, artistic and sportive environments and educational environments should be created and conditions of existing environments may 
be improved to contribute to the happiness levels of the prospective teachers. Positive changes may also be made in the attitudes of prospective teachers towards the teaching profession.

1.2. As a result of the research, the happiness levels of married students and their attitudes towards teaching profession have been found to be lower than those of single students. It is possible to increase the number of implementations for encouraging married students to fulfill their responsibilities. At that point, it is possible for the universities to search the problems of the married students and prepare action plans in this regard.

2. Recommendations for Further Research

2.1. This research has analyzed the relationship between the happiness levels of pedagogical formation students and their attitudes towards the teaching profession along with the influence of happiness on the teaching profession. Different researches may be conducted on the relationship between happiness and different variables such as anxiety, personality traits, self-efficacy perceptions, proficiency of training environments, and the effects of those who raise teachers.

2.2. Qualitative researches may be carried out in order to examine the match between happiness and attitude towards teaching profession.

\section{Acknowledgments}

This article is an extented version of the paper orally presented at 27 th International Congress on Educational Sciences held in Antalya, 18-22 April 2018. 


\section{Öğretmenlik Mesleğine Yönelik Tutumun Bir Yordayıcısı Olarak Mutluluk: Pedagojik Formasyon Örneği}

\section{Giriş}

Eğitim sistemlerinin temel amacı nitelikli insan gücünün yetiştirilmesi ve yurttaşlar üzerinde vatandaşlık bilinci oluşturulmasıdır (Temizkan, 2008). Nitelikli insan gücünün yetiştirilebilmesi için de nitelikli öğretmenlere ihtiyaç vardır. Çünkü yeni nesillerin niteliği hiç kuşkusuz onu yetiştiren öğretmenlerin niteliği ile özdeş olacaktır (Çelikten, Şanal \& Yeni, 2005). Toplumun eğitimden beklediği değerleri yerine getirmede en önemli faktör öğretmen faktörüdür (Azar, 2011). Bu bakımdan öğretmenlik, toplumlar tarafından kutsal olarak kabul edilen saygın bir meslektir.

Ülkeler geleceklerini öğretmenlere teslim etmekte, geleceklerinin temellerini bugünün öğretmenleri ile inşa etmektedirler. Bu yönüyle öğretmenler eğitim sistemlerinin vazgeçilmez unsurlarıdır. Dünyada yaşanan bilimsel ve teknolojik gelişmeler öğrenmeyi kolaylaştırmaktadır. Ancak yaşanan gelişmeler öğrenmeyi her ne kadar kolaylaştırsa da öğretmenlerin eğitim sistemleri için vazgeçilmez unsur olma özellikleri her zaman söz konusu olmaya devam etmektedir (Can, 2010).

Eğitim sistemleri açısından önemli bir yere sahip olan öğretmenlerin psikolojik yönden iyi olmaları eğitsel amaçlara ulaşma bakımından önem arz etmektedir. Psikolojik iyi olma durumunun göstergelerinden birisi de sahip olunan mutluluk ve bu mutluluğun düzeyidir. Çünkü mutluluk ile bireyin yaşam kalitesi arasında sıkı bir ilişki vardır (Kangal, 2013). Sahip olunan mutluluğun, öğretmene kaliteli bir çalışma hayatı sağlayacağı, aksi durumda ise mutsuzluk düzeyine göre değişecek oranlarda niteliksiz bir çalışma hayatı sunacağı ifade edilebilir (Demir, 2017). Bu bakımdan öğretmenlerin mutlu olup olmamaları eğitim öğretimin niteliğine etki eden önemli bir unsur olarak değerlendirilebilir. Mutluluk durumunun, öğretmenin çalışma ve özel hayatı açısından dolayısıyla eğitim öğretim sürecinin niteliği bakımından taşıdığı bu öneminden hareketle öğretmen adayı konumunda olan pedagojik formasyon öğrencilerinin mutluluk düzeylerinin incelenmesine ihtiyaç duyulmuş, pedagojik formasyon öğrencilerinin mutluluk düzeylerinin öğretmenlik mesleğine yönelik tutumlarına etkisi bu araştırma kapsamında belirlenmeye çalışılmıştır.

\section{Mutluluk}

Mutluluk konusu, ilk çağlardan günümüze kadar insanların ilgisini çekmiş ve üzerine pek çok araştırma yapılmıştır (Doğan, Sapmaz \& Çötok Akıncı, 2013). Mutluluk, insanı fizyolojik, psikolojik, bilişsel, sosyal dinsel vs. tüm yönleriyle çevreleyen bir kavramdır (Demir, 2017). İnsanlar mutluluğu, yaşadıkları yer, zaman, kültür, felsefi veya dini inanış açısından yorumlamaya ve anlamaya çalışmışlardır. Çünkü mutlu insanlar, diğer insanlara göre çok daha neşelidirler, umut doludurlar ve çoğu şeyden keyif duyabilirler (Tingaz, 2013).

Mutluluk, insanoğlunun istek ve beklentilerini elde ettikçe sahip olduğu ruh halidir (Duran, 2016). Farabi'ye göre mutluluk ancak erdemle ulaşılabilen ve karşıtı bedbahtlık olan bir olgudur. Kişinin elde edebileceği en büyük olgu mutluluktur (Özgen, 1997). Descartes'e göre mutluluk, ruhun tam anlamiyla bir memnuniyet ve hoşnut olma durumudur (Aydoğan, 2015). Mutluluk, insanın özünde yer alan güçlerinin farkına varması ve bunları gerçekleştirmesi, ödevlerini yerine getirmesi, erdemli olması, doğaya saygılı bir yaşam sürmesi ve kendi yazgısını özgürce belirleyebilmesi sonucunda oluşan yetkinlik durumudur (Cevizci, 2003). Mutluluk, insanların üzerinde uzun zaman etkisini sürdüren ve doyurulmuş bir dizi hazlar bütününden oluşan olumlu bir duygudur (Franklin, 2010). Nesnel manada mutluluk; yaşam koşullarının iyi, savaşın olmadığı, huzur ve özgürlüğün yoğun olduğu ortamda yer almaktır. Öznel manada mutluluk ise gelip geçici duyguların yol açtığı ruhsal bir durumdur (Veenhoven, 2000: Akt: Yalçın, 2016). Mutluluk teriminin psikolojideki karşılığı ise "öznel iyi oluş" tur (Eryılmaz, 2011). Öznel iyi oluş, bireylerin daha çok olumlu duygulara sahip olmaları, olumsuz duyguları az yaşamaları ve bireylerin hayatlarından daha fazla doyum almalarını ifade eder (Hybron, 2000).

İnsanoğlunun yüzyıllardır aradığı mutluluk olgusu, günümüzde değişen koşulların meydana getirdiği olumsuz etkiler sonucunda daha fazla ihtiyaç duyulan bir kavram haline gelmiştir (Baysal \& Aka, 2013). Bu ihtiyac1 karşılamanın yolu Freud'a göre insanların içgüdüsel isteklerinin doyurulmasından geçer (Froom, 1995). Russel (2003) ise mutluluğun yolunun ilgi ve umutlarımızı olabildiğince genişletmekten geçtiğini belirtmektedir. Mutluluğun yakalanması için iki adım vardır. Bunlardan birincisi bireyin kendisinin farkında olması, ikincisi ise bireyin insanlarla iletişim halinde olmasıdır (Tarhan, 2013).

İnsanlar için vazgeçilmez bir ihtiyaç olan mutluluğun farklı şekillerde sınıflandırıldı̆̆ı görülmektedir. Ancak literatürde temel olarak hazsal ve anlamsal olmak üzere iki farklı mutluluk kavramı öne çıkmaktadır. Hazsal 
mutluluk yaklaşımına göre mutluluk; bir duyguyu ifade etmekte olup kişinin o anda yaşadığı zevk ve hazların toplamını ifade eder. Anlamsal mutluluk ise erdemler ve değerlerle ilişkilidir. Bu yaklaşıma göre ise mutluluk, erdem ve değerlerin yaşama anlam kazandırmasıdır (Ryan \& Deci, 2001).

\section{Tutum}

Çağdaş eğitim sistemlerinde hedef; problem çözebilen, bilgiye ulaşabilen, analitik düşünen ve öğrenme isteğini sürekli canlı tutabilen bireyler yetiştirmektir (Akpınar, Yıldız, \& Ergin, 2006). Eğitim sistemlerinin bu hedeflerine ulaşabilmesi, büyük oranda öğretmenlerin niteliğine yani öğretmenlerin öğretmenlik mesleğinin yeterliliklerine sahip olma durumlarına bağlıdır. Öğretmenlik mesleği sosyal, kültürel, ekonomik, bilimsel ve teknolojik olmak üzere birden fazla boyutu olan, özel uzmanlık bilgisi, mesleki beceri ve profesyonellik gerektiren bir meslektir (Erden, 1998). Öğretmenlik mesleği, sabır, özveri ve sürekli çalışma gerektirir. Bu meslekte başarıya ulaşmak için, mesleki manada sevgi ve isteğin varlığı zorunludur (Çapa \& Çil, 2000). Bu da ancak mesleğe karşı öğretmenin olumlu bir tutum geliştirmesi ile mümkündür.

İnsan bireyselliğinin merkez parçası olan tutum (Bohner \& Wanke, 2002), kişinin yaşamındaki olaylara karşı zihinsel süreçlerini kalıcı, duygusal ve güdüsel olarak örgütlemesidir (Krech \& Grutchfield, 1965: Akt.: Temizkan, 2008). Tutumlar inanç ve değer yargılarına dayanırlar ve varlıklarını bu olgular üzerinden devam ettirirler (Çiçek Sağlam, 2008). Kişinin herhangi bir mesleğe yönelik tutumu, o mesleği nasıl yapacağının öncülüdür (Şenel, Demir, Sertelin, K1lıçaslan, \& Köksal, 2004). Bu bakımdan öğretmenlik mesleğine ilişkin tutumun, eğitim öğretimin niteliği ile doğrudan bağlantılı olduğu ifade edilebilir.

Nitelikli öğretmenin yetiştirilmesi ve öğretmen yetiştirme programında başarının artırılabilmesi için öğretmen adaylarının öğretmenlik mesleğine ilişkin tutum ve görüşlerinin belirlenmesi ve varsa olumsuz tutumların olumluya dönüștürülmesi zorunludur (N. Semerci \& C.. Semerci, 2004). Öğretmenlik mesleğine yönelik olumlu tutum sahibi olma ve mesleki anlamda algılanan yeterlilik, öğretmen adaylarının mesleklerini gelecekte nasıl algıladıklarının bir yansımasıdır (Şahin, Zade, \& Direk, 2009). Öğretmenin kişiliği, mesleki yeterliliği ve öğretmenlik mesleğine yönelik tutumu mesleki açıdan büyük önem taşımaktadır (Alım \& Bekdemir, 2006). Çünkü öğretmenlerin mesleğe yönelik bakış açılarının olumlu olması, onları mesleğe adım attıklarında daha özverili ve daha etkili bir öğretmen yapacaktır (Erdem, Gezer, \& Çokadar, 2005).

Öğretmen adaylarında öğretmenlik mesleğine yönelik olumlu tutumun artması, mesleki sorumluluklarının farkında olmalarını, yeni eğitim modellerini kavramalarını, öğrenme teorilerini, pedagojik yöntem ve eğitim programlarını sorgulamalarını ve yeniden tasarlama becerisi geliştirmelerini sağlayacaktır (Akkaya, 2009). Öğretmenlerin sahip oldukları olumlu mesleki tutum, onların öğretmenlik mesleğini içtenlikle ve isteklilikle yapmalarına ve mesleklerinde daha başarılı olmalarına katkıda bulunacaktır (Çiçek Sağlam, 2008). Bu bakımdan öğretmenlerin mesleklerine, hedef kitleleri olan öğrencilerine ve ayrıca okul içerisinde yapılan tüm eğitsel faaliyetlere dönük tutumlarının, öğrenci kişiliğinin oluşturulmasında ve öğrencilerin öğrenmelerinde büyük oranda katkı sunacağı ifade edilebilir (Küçükahmet, 2003). Öğretmenlerin mesleğe yönelik olumlu tutum düzeylerinin yüksek olması, öğretmen ile ilişkili bütün unsurları etkileyecektir (Baykara Pehlivan, 2008). Bu nedenle olumlu mesleki tutuma sahip öğretmen adaylarının yetiştirilmesi, onların göreve başladıktan sonraki süreçlerde görevlerini daha eksiksiz olarak yapmalarına, okula ve öğrencilere yönelik olumlu davranış sergilemelerine, araştırıcı ve yaratıcı düşünen bireyler olmalarına ayrıca alandaki yenilikleri öğrenme ortamlarına aktarmalarına katkı sağlayacaktır (Temizkan, 2008).

Öğretmenlik mesleği açısından bu denli önemli bir yere sahip olan olumlu mesleki tutumun varlığı sadece bir sebebe, bir duruma ya da bir değişkene bağlı değildir. Öğretmen adaylarında, öğretmenlik mesleğine yönelik olumlu tutumun varlığında pek çok değişkenin etkili olduğu (Usta \& Korkmaz, 2010), olumlu tutumun varlığının, yokluğunun, miktarının ve niteliğinin bu değişkenlerle ilintili olduğu belirtilebilir. Öğretmen adaylarının mesleğe yönelik tutumlarının bilinmesi, gerekli değerlendirilmelerin yapılmasına imkân sunar. Yapılacak değerlendirmeler sonrası aday öğretmenlerde olumlu mesleki tutum geliştirebilme yönünde atılacak adımlarla birlikte eğitim kalitesine katkı sunulabilir. Bu katkının eğitim sistemi açısından önemli olduğu ifade edilebilir. Bu önemden dolayı pedagojik formasyon eğitimi sürecindeki öğretmen adaylarının mutluluk düzeyleri ile öğretmenlik mesleğine yönelik tutumları arasında ilişkinin var olup olmadığı, varsa bu ilişkinin yönü ve düzeyinin ne olduğu; mutluluğun öğretmenlik mesleğine yönelik tutumu etkileyip etkilemediği bu araştırmada ortaya konulmaya çalışılmıştır. Araştırmanın bu yönüyle alana katkı sunacağı düşünülmektedir. Bu düşünceden hareketle araştırmanın temel amacı; "pedagojik formasyon eğitimi alan öğrencilerin mutluluk düzeyleri ile öğretmenlik mesleğine yönelik 
tutumları arasındaki ilişkinin incelenmesi” şeklinde ifade edilmiştir. Bu amaç çerçevesinde aşağıdaki sorulara cevap aranmıştır:

1. Pedagojik formasyon öğrencilerinin mutlulukları hangi düzeydedir?

2. Pedagojik formasyon eğitimi alan öğrencilerin mutluluk düzeyleri bazı demografik değişkenler yönünden farklılaşmakta mıdır?

3. Pedagojik formasyon eğitimi alan öğrencilerin öğretmenlik mesleğine yönelik tutumları hangi düzeydedir?

4. Pedagojik formasyon öğrencilerinin öğretmenlik mesleğine karşı tutumları bazı demografik değişkenler yönünden farklılaşmakta mıdır?

5. Pedagojik formasyon öğrencilerinin mutluluk düzeyleri ile öğretmenlik mesleğine ilişkin tutumları arasında ilişki var mıdır? Varsa bu ilişkinin yönü ve düzeyi nedir?

6. Pedagojik formasyon öğrencilerinin mutluluk düzeyleri onların öğretmenlik mesleğine karşı tutumlarını ne düzeyde yordamaktadır?

\section{Yöntem}

Araştırmanın modeli, evren ve örneklemi, araştırmada kullanılan veri toplama araçları ve verilerin analizine ilişkin bilgilere bu bölümde yer verilmiştir.

\section{Araștırma Modeli}

Araştırma iliş̧isel tarama modelinde gerçekleştirilmiş nicel bir çalışmadır. İlişkisel tarama şeklinde modellenen araştırmalarda iki veya daha çok sayıdaki değişken arasında birlikte değişimin varlı̆̆ $/$ derecesi belirlenmeye çalışılır (Karasar, 2016). Bu araştırmada pedagojik formasyon öğrencilerinin öğretmenlik mesleğine yönelik tutumları ile mutluluk düzeyleri arasındaki ilişkiye odaklanılmıştır. Ayrıca mutluluk değişkeninin öğretmenlik mesleğine yönelik tutumu ne düzeyde yordadığı ortaya konulmaya çalışılmıştır.

\section{Evren ve Örneklem}

Araştırmanın evreni 2015-2016 Eğitim Öğretim y1lı bahar döneminde Sütçü İmam Üniversitesi Eğitim Fakültesi bünyesinde verilen pedagojik formasyon eğitimine katılan 344 öğrenciden oluşmaktadır. Araş̧ırma evrenin tamamı araştırma örneklemi olarak belirlenmiş ve toplamda 338 öğrenciden araştırma verileri elde edilmiştir. Örnekleme ait demografik özellikler Tablo 1'de verilmiştir.

Tablo 1: Araştırmaya Katılan Örnekleme Ait Demografik Özellikler

\begin{tabular}{|c|c|c|c|c|c|c|c|c|c|}
\hline $\begin{array}{l}\text { Demografik } \\
\text { Değişken }\end{array}$ & Erkek & Kadın & Evli & Bekâr & Mezun & Öğrenci & $\begin{array}{l}20-25 \\
\text { Yaş }\end{array}$ & $\begin{array}{l}\text { 26-29 } \\
\text { Yaş }\end{array}$ & $\begin{array}{l}29 \text { Yaş } \\
\text { ve Üzeri }\end{array}$ \\
\hline Cinsiyet & $\begin{array}{l}140 \\
(\% 41,4)\end{array}$ & $\begin{array}{l}198 \\
(\% 58,6)\end{array}$ & & & & & & & \\
\hline $\begin{array}{l}\text { Medeni } \\
\text { Durum }\end{array}$ & & & $\begin{array}{l}64 \\
(\% 19)\end{array}$ & $\begin{array}{l}274 \\
(\% 81)\end{array}$ & & & & & \\
\hline $\begin{array}{l}\text { Mezuniyet } \\
\text { Durumu }\end{array}$ & & & & & $\begin{array}{l}79 \\
(\% 23,3)\end{array}$ & $\begin{array}{l}259 \\
(\% 76,7)\end{array}$ & & & \\
\hline Yaş & & & & & & & $\begin{array}{l}75 \\
(\% 22,2)\end{array}$ & $\begin{array}{l}164 \\
(\% 48,5)\end{array}$ & $\begin{array}{l}99 \\
(\% 29,3)\end{array}$ \\
\hline
\end{tabular}

\section{Veri Toplama Araçları}

Araştırmada kullanılan veri toplama aracının ilk kısmında, katılımcıların cinsiyet, medeni durumu ve eğitim durumu gibi demografik özelliklerini belirlemeye yönelik sorular yer almaktadır. İkinci kısımda pedagojik 
formasyon öğrencilerinin mutluluk düzeylerini belirlemeye yönelik ölçek, son kısımda ise pedagojik formasyon öğrencilerinin öğretmenlik tutumlarını belirlemeye yönelik ölçek yer almaktadır.

Pedagojik formasyon öğrencilerinin mutluluk düzeylerini belirlemek amacıyla Hills ve Argyle (2002) tarafından geliştirilen, Doğan ve Çötok (2011) tarafından da Türkçeye uyarlanarak geçerlik ve güvenirlik çalışmaları yapılan "Oxford Mutluluk Ölçeği Kısa Formu" kullanılmıştır. Tek faktör ve 7 maddeden oluşan ölçeğin güvenirlik çalışmasında ölçeğin güvenirlik düzeyi .85 olarak saptanmıştır. Bu araştırmada ise ölçeğin güvenirlik düzeyi .70 bulunmuştur.

Pedagojik formasyon öğrencilerinin öğretmenlik mesleğine karşı tutumlarını belirlemek amacıyla Bulut (2009) tarafından geliştirilen ve Atalmış (2016) tarafından geçerlik ve güvenirlik çalışması yapılan "Öğretmenlik Mesleği Tutum Ölçeği” kullanılmıştır. "Öncelik, Niteliklilik, Olumsuzluk ve İsteklilik" olmak üzere 4 faktörden ve 20 maddeden oluşan ölçeğin güvenirlik çalışmasında ölçeğin genelinin güvenirlik düzeyi .81 olarak saptanmıştır. Ölçeğin güvenirlik çalışmasında alt boyutlarının güvenirlik düzeyleri; Öncelik boyutunun .57, Niteliklilik boyutunun .55 , Olumsuzluk boyutunun .56 ve İsteklilik boyutunun .71 olduğu görülmüştür. Bu araştırmada ise ölçeğin geneline ait güvenirlik düzeyinin .85 olduğu görülmüştür. Tutum ölçeği boyutlarının güvenirlik düzeylerine bakıldığında Öncelik boyutunun “.57”, Niteliklilik boyutunun “.61”, Olumsuzluk boyutunun “.58” ve İsteklilik boyutunun ".83" olduğu belirlenmiştir.

Ölçek maddelerine verilen cevaplar beşli likert şeklinde derecelendirilmiştir. Veri toplama araçlarında yer alan her bir maddenin gerçekleşme düzeyini belirlemek için "Tamamen Katılıyorum (5)", "Katıllyorum (4)", "Kısmen Katılıyorum (3)", "Katılmıyorum (2)" ve "Hiç Katılmıyorum (1)" dereceleri kullanılmıştır. Ölçek maddelerinden alınacak puan aralıkları ise 1.00-1.80 arası puan "Hiç Katılmıyorum"; 1.81-2.60 arası puan "Katılmıyorum"; 2.613.40 puan arası "Az/Biraz Katıliyorum"; 3.41-4.20 "Katılıyorum"; 4.21-5.00 "Tamamen Katıllyorum" şeklinde derecelendirme yapılmıştır.

\section{Verilerin Analizi}

Pedagojik formasyon öğrencilerinin mutluluk düzeyleri ile öğretmenlik mesleğine ilişkin tutumlarına ilişkin veriler SPSS for Windows 21.0 programı ile analiz edilmiştir. Veri analizinde aritmetik ortalama ve standart sapma değerleri hesaplanmıştır. Veriler üzerinde yapılan normallik testinde dağılımın normal olduğu görülmüştür.

Tablo 2: Normallik Testi Sonuçları

\begin{tabular}{llllll}
\hline \multirow{2}{*}{ Değişkenler } & \multirow{N}{*}{} & Skewness & \multicolumn{3}{c}{ Kurtosis } \\
\cline { 3 - 6 } & & Statistic & Std. Error & Statistic & Std. Error \\
\hline Mutluluk & 338 &,- 392 &, 133 &, 172 &, 265 \\
Tutum & 338 &,- 864 &, 133 &, 827 &, 265 \\
\hline
\end{tabular}

Tablo 2'tde görüldüğü gibi Skewness değerleri -1 ile +1 arasındadır. Bu değerler dağılımın normal olduğunu göstermektedir. Verilerin dağılımı normal olduğundan dolayı tutum ve mutluluk değişkenlerinin bazı demografik değişkenlere göre farklılaşıp farklılaşmadığını tespit etmek amacıyla t testi kullanılmıştır. İlişkisel hesaplamalarda ise korelasyon (r) ve regresyon analizi yapılmıştır.

\section{Bulgular}

Çalışmanın bu bölümünde araştırma kapsamında elde edilen bulgulara yer verilmiştir. Bulgular araştırmanın alt problemleri doğrultusunda oluşturulan başlıklar halinde açıklanmıştır.

\section{Pedagojik Formasyon Öğrencilerinin Mutluluk Düzeyleri ve Öğretmenlik Mesleğine Karşı Tutumlarına İliş̧kin Bulgular}

Pedagojik formasyon öğrencilerinin mutluluk düzeyleri, öğretmenlik mesleğine karşı tutumları ve tutum ölçeğinin alt boyutlarına ilişkin ortalamaları ile standart sapma değerleri Tablo 3 'te verilmiştir. 
Tablo 3: Pedagojik Formasyon Öğrencilerinin Mutluluk Düzeyleri ve Öğretmenlik Mesleğine Karş1 Tutumlarının Ortalama ve Standart Sapma Değerleri

\begin{tabular}{llll}
\hline Ölçekler & $\mathbf{N}$ & $\overline{\mathbf{x}}$ & $\mathbf{S}$ \\
\hline Mutluluk & 338 & 2,96 & 1,07 \\
\hline Öğretmenlik Mesleğine Yönelik Tutum (Genel) & 338 & 3,86 &, 915 \\
İsteklilik & 338 & 4,31 &, 856 \\
Olumsuzluk & 338 & 3,13 & 1,19 \\
Niteliklilik & 338 & 4,56 &, 690 \\
Oncelik & 338 & 4,01 &, 983
\end{tabular}

Tablo 3'e bakıldığında, araştırmaya katılan pedagojik formasyon öğrencilerinin mutluluk düzeyi ortalamalarının ( $\overline{\mathrm{X}}=2,96)$ “Az Katılıyorum” düzeyinde; öğretmenlik mesleğine yönelik tutumlarının ise $(\overline{\mathrm{X}}=3,86)$ "Katılıyorum" düzeyinde olduğu ortaya çıkmıştır. Araştırma örneklemini oluşturan pedagojik formasyon öğrencilerinin mutluluklarının orta düzeyde olduğu bunun yanında öğretmenlik mesleğine karşı olumlu tutum sergiledikleri görülmektedir.

2. Pedagojik Formasyon Öğrencilerinin Bazı Demografik Özellikleri Açısından Mutluluk ve Öğretmenlik Mesleğine Yönelik Tutum Düzeylerinin İncelenmesi

Bazı demografik değişkenler açısından pedagojik formasyon öğrencilerinin mutluluk ve öğretmenlik mesleğine yönelik tutum düzeylerinin ne kadar değiştiğine ilişkin veriler Tablo 4'te sunulmuştur.

Tablo 4: Pedagojik Formasyon Öğrencilerinin Mutluluk ve Öğretmenlik Mesleğine Yönelik Tutumlarının Bazı Demografik Özelliklerine Göre Karşılaştırılması

\begin{tabular}{|c|c|c|c|c|c|c|c|c|}
\hline \multirow[t]{2}{*}{ Değişkenler } & \multicolumn{2}{|c|}{ Cinsiyet } & \multicolumn{2}{|c|}{$\begin{array}{l}\text { Medeni } \\
\text { Durum }\end{array}$} & \multicolumn{2}{|c|}{$\begin{array}{c}\text { Mezun Olma } \\
\text { Durumu }\end{array}$} & \multicolumn{2}{|l|}{ Yaş } \\
\hline & $\mathbf{t}$ & $\mathbf{p}$ & $\mathbf{t}$ & $\mathbf{p}$ & $\mathbf{t}$ & $\mathbf{p}$ & $\mathbf{F}$ & $\mathbf{p}$ \\
\hline Mutluluk & $-1,641$ & ,101 & $-2,625$ & ,009* & 1,591 & ,113 & ,786 & 456 \\
\hline $\begin{array}{l}\text { Öğretmenlik Mesleğine Yönelik } \\
\text { Tutum }\end{array}$ & $-1,499$ & ,135 & $-2,293$ &, $022^{*}$ & 1,300 & ,195 & ,982 & ,376 \\
\hline İsteklilik & $-1,174$ &, 241 & $-2,054$ &, $041^{*}$ &, 575 &, 566 & ,867 & ,421 \\
\hline Olumsuzluk &,- 839 & ,402 &,- 764 &, 445 & 1,620 & , 106 & 1,012 & ,364 \\
\hline Niteliklilik & $-1,763$ & 079 & $-1,954$ & ,052 & 1,755 &, 080 & 1,194 & ,304 \\
\hline Öncelik &,- 759 & ,449 & $-2,366$ &, $019^{*}$ & ,819 & ,413 & 990 & ,373 \\
\hline
\end{tabular}

$* \mathrm{p}<.05$

Tablo 4'te yer alan bulgular incelendiğinde pedagojik formasyon öğrencilerinin mutluluk düzeylerinin cinsiyetlerine göre anlamlı farklılık göstermediği görülmektedir. Bu bulguya göre pedagojik formasyon öğrencilerinin kadın ya da erkek olmalarının onların mutluluk düzeylerine etki etmediği söylenebilir. Pedagojik formasyon öğrencilerinin mutluluk düzeylerinin medeni durumlarına göre anlamlı farklılık gösterdiği görülmüşsür $\left[\mathrm{t}_{(342)}=-2,625, \mathrm{p}<, 05\right]$. Sıra ortalamaları dikkate alındığında, bekâr katılımcıların lehine bir durumun söz konusu olduğu görülmektedir $\left(\overline{\mathrm{X}}_{\text {Evli }}=3,51 ; \overline{\mathrm{X}}_{\text {Bekâr }}=3,66\right)$. Bekâr öğrencilerin evli öğrencilere göre daha mutlu olmaları, sorumluluklarının evlilere oranla daha az olması, ekonomik anlamda burslarla ve/veya ailelerinden destek 
görmeleri, evli öğrencilere göre daha rahat hareket edebilmeleri gibi farklı birçok nedenden kaynaklandı̆̆ söylenebilir. Pedagojik formasyon öğrencilerinin mutluluk düzeylerinin onların mezun olma durumlarına göre ve yaşlarına göre anlamlı bir farklılaşmanın olmadığı ortaya çıkmıştır.

Tablo 4 incelendiğinde, pedagojik formasyon öğrencilerinin öğretmenlik mesleğine yönelik tutumlarına ilişkin

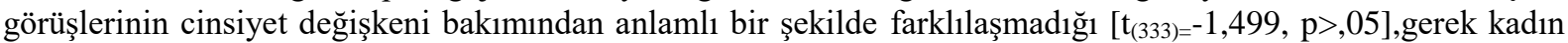
gerekse erkek katılımcıların öğretmenlik mesleğine yönelik tutumlarının yüksek düzeyde olduğu, her iki gurubun da öğretmenlik mesleğine yönelik tutumlarının "Katılıyorum" düzeyinde olduğu görülmüştür $\left(\overline{\mathbf{X}}_{\text {Erkek }}=4,06\right.$; $\left.\overline{\mathrm{X}}_{\text {Kadın }}=4,14\right)$. Pedagojik formasyon öğrencilerinin mezuniyet durumları ve yaşları ile öğretmenlik mesleğine yönelik tutumları ve alt boyutlarında anlamlı bir farklılaşmanın olmadığı görülmüştür.

Araştırma örnekleminin medeni durumları yönünden mesleki tutumlarına ilişkin görüşleri arasında anlamlı bir farklılaşmanın olduğu görülmüştür $\left[\mathrm{t}_{(336)}=-2,293, \mathrm{p}<, 05\right]$. Sıra ortalamalarına bakıldığında bekâr öğrencilerin evli öğrencilere göre öğretmenlik mesleğine yönelik tutumlarının daha olumlu olduğu belirlenmiştir $\left(\overline{\mathrm{X}}_{\text {Evli }}=4,08 ; \overline{\mathrm{X}}_{\text {Bekâr }}\right.$ $=4,23$ ). Öğretmen adaylarının mesleğe yönelik tutumlarının, onların mezun olma durumlarına göre anlamlı bir farklılık göstermediği de görülmüştür. Öğretmenlik mesleğine yönelik tutumun alt boyutlarına bakıldığında ise isteklilik alt boyutunda katılımcıların medeni durumları açısından bekâr katılımcıların lehine anlamlı bir farklılık olduğu $\left(\overline{\mathbf{X}}_{\text {Evli }}=4,28 ; \overline{\mathbf{X}}_{\text {Bekâr }}=4,47\right)$; öncelik alt boyutunda da ise bekâr katılımcıların lehine anlamlı bir farklılık olduğu $\left(\overline{\mathrm{X}}_{\text {Evli }}=2,38 ; \overline{\mathrm{X}}_{\text {Bekâr }}=2,52\right)$ diğer alt boyutlarda ise anlamlı bir farklılaşmanın olmadığı görülmüştür.

\section{Pedagojik Formasyon Öğrencilerinin Mutluluk Düzeyleri ve Öğretmenlik Mesleğine Yönelik Tutumları Arasındaki İlişkinin İncelenmesi}

Pedagojik formasyon öğrencilerin mutluluk düzeyleri ile öğretmenlik mesleğine yönelik tutumları arasındaki ilişkiyi ortaya koymak amacıyla yapılan Pearson Korelasyon testi sonuçları Tablo 5’te verilmiştir.

Tablo 5: Pedagojik Formasyon Öğrencilerinin Mutluluk Düzeyleri ile Öğretmenlik Mesleğine Yönelik Tutumları Arasındaki İlişki

\begin{tabular}{lll}
\hline & Mutluluk & Tutum \\
\hline Mutluluk & 1 & \\
$\mathbf{p}$ & & 1 \\
Tutum &, $223^{*}$ & \\
$\mathbf{p}$ &, 000 &
\end{tabular}

Pedagojik formasyon öğrencilerinin mutluluk düzeyleri ile öğretmenlik mesleğine yönelik tutumları arasında düşük düzeyde, pozitif ve anlamlı bir ilişki olduğu görülmüştür. Buna göre öğrencilerin mutluluk düzeyleri arttıkça, öğretmenlik mesleğine yönelik tutumlarının da artacağı söylenebilir.

\section{Pedagojik Formasyon Öğrencilerinin Mutluluk Düzeylerinin Öğretmenlik Mesleğine Yönelik Tutumlarına Etkisi}

Pedagojik formasyon öğrencilerinin mutluluk düzeylerinin öğretmenlik mesleğine yönelik tutumu ne düzeyde yordadığını ortaya koymak için yapılan regresyon analizine ilişkin sonuçlar Tablo 6'dae verilmiştir.

Tablo 6: Pedagojik Formasyon Öğrencilerinin Mutluluk Düzeylerinin Öğretmenlik Mesleğine Yönelik Tutumlarına Etkisine Dair Regresyon Analizi Sonuçları

\begin{tabular}{llllllll}
\hline $\begin{array}{l}\text { Bağımlı } \\
\text { Değişken }\end{array}$ & $\begin{array}{l}\text { Bağımsız } \\
\text { Değişken }\end{array}$ & $\mathbf{B}$ & Shata & $\boldsymbol{\beta}$ & $\mathbf{T}$ & $\mathbf{p}$ & Durbin Watson \\
\hline Mutluluk & Sabit & 69,868 & 2,848 & & 24,534 &, 000 & \\
& Tutum &, 505 &, 115 &, 233 & 4,392 &, 000 & 2,12 \\
& & & & & & & \\
\hline
\end{tabular}

$\mathrm{R}=, 233 \quad \mathrm{R}^{2}=, 054 \quad \mathrm{~F}=19,289 \quad \mathrm{P}=, 000$


Tablo 6'ya bakıldığında Regresyon modeline ait Durbin Watson değerinin 2.12 olduğu görülmektedir. Hata terimleri arasında bir korelasyon bulunup bulunmadığını ortaya koyan Durbin Watson testinin istatistik değerinin 2'ye yakın olmasının hata terimleri arasında bir korelasyonun olmadığını işaret ettiği ve bunun da regresyon analizinde olumlu bir durum olduğu göz önünde bulundurulduğunda 2.12 değerinin regresyon modeli için kabul edilebilir bir değer olduğu ifade edilebilir. Yine Tablo 6'da görüldüğü gibi yapılan basit doğrusal regresyon analizine göre pedagojik formasyon eğitimi alan ögrencilerin mesleki tutumlarına ilişkin toplam varyansın $\% 5^{\prime} i$ mutluluk değişkeni ile açıklanmakta ve öğrencilerin mutluluk düzeyleri onların öğretmenlik mesleğine yönelik tutumlarını pozitif yönde anlamlı bir şekilde etkilemektedir.

\section{Sonuç, Tartışma ve Öneriler}

Araştırma sonucuna göre pedagojik formasyon öğrencilerinin mutluluk düzeylerinin orta düzeyde olduğu söylenebilir. Çünkü mutluluk ölçeğinden alınan puanların yüksekliği bireyin mutluluk düzeyinin yükseldiğini ifade etmektedir (Doğan ve Sapmaz, 2012). Ölçekten alınabilecek en düşük puanın 7; en yüksek puanın 35 olduğu dikkate alındığında, pedagojik formasyon öğrencilerinin mutluluk ölçeğinden aldıkları toplam 20 puanın orta düzey bir mutluluk düzeyini işaret ettiği belirtilebilir. Yazıcı (2015) tarafindan yapılan araştırmada da bu araştırmanın bulgularına paralel olarak pedagojik formasyon eğitimi alan öğrencilerin mutluluklarının orta düzeyde olduğu görülmüştür. Üniversite öğrencilerinin mutlulukları üzerine yapılan farklı bir araştırmada ise öğrencilerin mutluluk düzeylerinin yüksek olduğu sonucuna ulaşılmıştır (Aksoy, Güngör Aytar \& Kaytez, 2016). Pedagojik formasyon eğitimi alan öğrencilerin mutluluk düzeylerinin yüksek olmamasına sebep olarak bu öğrencilerden bir lisans programına devam edenlerin aynı anda lisans ve pedagojik formasyon eğitimi almalarından dolayı yaşadıkları yoğunluk gösterilebilir. Lisans öğrenimini tamamlamış olan pedagojik formasyon öğrencilerinin çoğunlukla henüz bir iş sahibi olamamaları; iş sahibi olanların ise iş ve eğitim yaşamlarını aynı anda yürütmeye çalışmalarından dolayı yaşayabilecekleri sıııntılar mutluluk düzeylerinin yüksek çıkmamasının olası nedenleri olarak ifade edilebilir.

Araştırmada elde edilen bir diğer sonuç ise pedagojik formasyon eğitimi alan öğrencilerin öğretmenlik mesleğine yönelik tutumlarının olumlu olmasıdır. Kaya ve Büyük kasap (2005), Gürbüz ve Kışoğlu (2007), Doğan ve Çoban (2009) ile Can'ın (2010) yapmış oldukları araştırmalar bu araştırmanın bulguları ile örtüşmektedir. Bunun yanında Akpınar, Yıldız ve Ergin (2006) tarafından Fen Bilgisi öğretmen adayları üzerinde yapılan araştırmada öğrencilerin öğretmenlik mesleğine yönelik tutumlarının orta seviyede olduğu bulgusuna ulaşılmıştır. Öğretmenlik mesleğine yönelik tutumu belirleyen değişkenlerden birisi de eğitimdir (Bursalığlu, 2012). Bu nedenle pedagojik formasyon sürecinde alınan öğretmenlik meslek eğitiminin öğrencilerin öğretmenlik mesleğine yönelik olumlu tutumlarının artmasına neden olduğu ifade edilebilir.

Pedagojik formasyon eğitimi alan öğrencilerin mutluluk düzeylerinin cinsiyet değişkeni açısından anlamlı bir şekilde farklılaşmadığı görülmüştür. Gönener, Öztürk ve Yılmaz (2017), Aksoy, Güngör ve Kaytez (2017) ve Akyüz, Yaşartürk, Aydın, Zorba ve Türkmen (2017) tarafından yapılan çalışmaların bulguları araştırmanın bu bulgusu ile örtüşmektedir. Gülcan ve Nedim Bal (2014) tarafından yapılan araştırmada ise genç yetişkinler üzerinde yapılan araştırmada cinsiyet ile mutluluk arasında anlamlı bir farklılaşma olduğu bulgusuna ulaşılmıştır. Anlamsal mutluluk anlayışına göre erdem ve değerlerin yaşama anlam kazandırması mutluluk olarak ifade edilmektedir (Ryan \& Deci, 2001). İnsanların taşıdıkları erdem ve değerlerin ve bunların yaşanma düzeylerinin farklı olması bireylerin mutluluk düzeylerinin bir belirleyicisi olacağı bu bakımdan da farklı örneklemlerin mutluluk düzeylerinin cinsiyet değişkenine göre değişebileceği belirtilebilir.

Araştırma sonucunda pedagojik formasyon öğrencilerinin cinsiyet değişkeni yönünden öğretmenlik mesleğine yönelik tutumları arasında anlamlı bir farklılaşmanın olmadığı görülmüştür. Bu bulgu Özder, Konedralı ve Perkan Zeki (2010) ile Demirtaş, Cömert ve Özer (2011) tarafından yapılan araştırmaların bulguları ile örtüşmektedir. Bunun yanında Çapa ve Çil (2000) ile Baykara Pehlivan (2008) tarafindan yapılan araştırmalarda öğretmen adaylarının cinsiyetleri ile onların mesleğine ilişkin tutumları arasında anlamlı farklılığın bulunduğu belirlenmiştir.

Pedagojik formasyon eğitimi alan öğrencilerin mutluluk düzeylerinin medeni durumları açısından anlamlı bir şekilde farklılaştığı görülmüştür. Bekâr öğrenciler evli öğrencilere oranla daha mutludurlar. Araştırmanın bu bulgusu Şentürk (2011) ve Cihangir (2005) tarafından yapılan araştırmaların bulguları ile örtüşmektedir. Habibzadeh ve Allahvirdiyani (2011) tarafından yapılan araştırmada ise medeni durum ile mutluluk arasında anlamlı bir farklılaşmanın olmadığı sonucuna ulaşılmıştır. Bu araştırma sonucunda ortaya çıkan, bekâr öğrencilerin 
evli öğrencilere göre daha mutlu oldukları bulgusu bekâr öğrencilerin taşıdıkları sorumluluklarının evli öğrencilere nispeten daha az olması ile açıklanabilir.

Araştırma sonucunda pedagojik formasyon eğitimi alan öğrencilerin medeni durumları ile öğretmenlik mesleğine yönelik tutumları arasında anlamlı bir farklılık olduğu görülmüştür. Bekâr öğrencilerin öğretmenlik mesleğine yönelik tutumları evli öğrencilere göre daha olumludur. Tutum bireyin hayatındaki olaylara karşı zihinsel süreçlerini kalıcı, duygusal ve güdüsel olarak örgütlemesidir (Krech \& Grutchfield, 1965: Akt.: Temizkan, 2008). Bekar öğrencilerin çoğunlukla yaşlarının evlilere göre küçük olması ve buna paralel olarak da zihinsel yıpranmalarının az olması öğretmenlik mesleğine yönelik tutumlarının evlilere göre daha olumlu olmasının bir nedeni olarak söylenebilir. Araştırma sonucunda ayrıca pedagojik formasyon eğitimi alan öğrencilerin gerek mutluluk düzeylerinin gerekse mesleğe yönelik tutumlarının mezun olma durumları ve yaş değişkeni açısından anlamlı bir şekilde farklılaşmadığı sonucuna ulaşılmıştır. .

Araştırma verilerine göre pedagojik formasyon eğitimi alan öğrencilerin mutluluk düzeyleri ile öğretmenlik mesleğine yönelik tutumları arasında düşük düzeyde, pozitif yönlü anlamlı bir ilişkinin olduğu ortaya çıkmıştır. Pedagojik formasyon eğitimi alan öğrencilerin mutluluk düzeylerinin, onların öğretmenlik mesleğine yönelik tutumlarının anlamlı bir yordayıcısı olduğu görülmüştür. Pedagojik formasyon öğrencilerinin mutluluk düzeylerini arttırıcı ortamların oluşturulması onların öğretmenlik mesleğine yönelik tutumlarının da olumlu yönde artmasını sağlayacaktır. Nitekim daha önce yapılan araştırmalar öğretmenlerin mesleklerine yönelik tutumlarının yüksek olmasının onların daha nitelikli ve etkili öğretmen olmalarını kolaylaştırdığını ifade etmektedir (Çiçek Sağlam, 2008; Erdem, Gezer \& Çokadar, 2005). Bu nedenle eğitim fakülteleri ve pedagojik formasyon eğitimi veren diğer fakültelerin, öğrencilerin öğretmenlik mesleğine yönelik tutumlarını artırıcı etkinliklere daha fazla yer ve zaman ayırması öğretmen adaylarının öğretmenlik mesleğine karşı tutumlarını olumlu yönde etkileyeceği dolayısıyla eğitim sisteminin niteliğine bu yönüyle katk1 sunulacağı belirtilebilir.

Araştırmanın sonucunda aşağıdaki önerilere yer verilmiştir.

1. Araştırmanın Bulgularına Dayalı Öneriler

1.1. Araştırma bulgularına göre öğrencilerin mutluluk düzeylerinin artmasının, onların öğretmenlik mesleğine yönelik tutumları üzerinde olumlu değişime sebep olduğu ortaya çıkmıştır. Bu nedenle öğretmen adayı olan ögrencilerin mutluluk düzeylerinin artmasına katkı sunacak sosyal, sanatsal, sportif ortamlar ile eğitim ortamlarının oluşturulması ve var olan ortamların şartlarının iyileştirilmesi sağlanabilir. Böylece öğretmen adaylarının öğretmenlik mesleğine yönelik tutumlarında da olumlu değişiklikler yaratılabilir.

1.2. Araştırma sonucunda evli öğrencilerin mutluluk düzeyleri ile öğretmenlik mesleğine yönelik tutumlarının bekâr öğrencilere oranla daha düşük düzeyde olduğu ortaya çıkmıştır. Evli öğrenciler için sorumluluklarını yerine getirmede kendilerine destek olacak uygulamaların arttırılması sağlanabilir. Bununla ilgili olarak evli öğrencilerin sorunlarını tespite dönük üniversiteler tarafından taramalar yapılıp bu tarama sonucunda eylem planları hazırlanarak bu planlar uygulamaya konulabilir.

2. Gelecekte Yapılacak Olan Araştırmalar için Öneriler

2.1. Bu araştırmada pedagojik formasyon eğitimi alan öğrencilerin mutlulukları ile öğretmenlik mesleğine yönelik tutumları arasındaki ilişki ve mutluluğun öğretmenlik mesleğine ilişkin tutuma etkisi incelenmiştir. Yapılacak farklı araştırmalarda öğretmenlik mesleğine yönelik tutumu etkileyebileceği düşünülen kaygı, kişilik özellikleri, öz yeterlik algısı, eğitim ortamlarının yeterlilikleri, öğretmen yetiştiricilerin etkileri gibi farklı değişkenler ile mutluluk arasındaki ilişki incelenebilir.

2.2. Bu araş̧ırmada nicel araştırma yöntemi kullanılarak incelenmiş olan mutluluk ile öğretmenlik mesleğine yönelik tutum arasındaki ilişkinin derinlemesine incelenebilmesi için nitel araştırma yöntemi kullanılarak farklı bir çalışma gerçekleştirilebilir.

\section{Bilgilendirme}

Bu çalışma, 18-22 Nisan 2018 tarihleri arasında Antalya'da düzenlenmiş olan 27. Uluslararası Eğitim Bilimleri Kongresinde sunulan sözlü bildirinin genişletilmiş halidir. 


\section{References}

Akkaya, N. (2009). Öğretmen adaylarının öğretmenlik mesleğine yönelik tutumlarının bazı değişkenlere göre incelenmesi [An investigation of prospective teachers' attitudes towards teachingin terms of some variables]. DokuzEylul University The Journal of Buca Faculty of Education (25), 35-42.

Akpınar, E., Yıldız, E., \& Ergin, Ö. (2006). Fen bilgisi öğretmen adaylarının öğretmenlik mesleğine yönelik tutumları [Attitudes of prospective science teachers towards the teaching profession]. DokuzEylul UniversityThe Journal ofBuca Facultyof Education (19), 56-62.

Aksoy, A.B., Güngör Aytar, A., \& Kaytez, N. (2016). Üniversite öğrencilerinin mutluluk ve alçakgönüllülük düzeylerinin bazı değişkenlere göre incelenmesi [Examination of the happiness and modesty levels of university students according to some variables]. Kastamonu Educational Journal 25(3), 1119-1132.

Akyüz, A.,Yaşartürk, F., Aydın, İ., Zorba, E. \& Türkmen, M. (2017). Üniversite öğrencilerinin yaşam kalitesi ve mutluluk düzeyleri arasındaki ilişkinin incelenmesi [Examining the relationship between the quality of life and happiness levels of university students]. International Journal of Cultural and Social Studies (IntJCSS), $3,253-262$.

Alım, M., \& Bekdemir, Ü. (2006). Coğrafya öğretmeni adaylarının öğretmenlik mesleğine yönelik tutumları [Attitudes of geography teacher candidates towards the teaching profession]. National Education Journal of Education and Social Sciences(172), 263-275.

Atalmış, E. H. (2016). Öğretmenlik mesleği tutum ölçeği kısa formu: güvenirlik ve geçerlilik çalışması [ The teaching profession attitude scale short form: reliability and validity study]. International Strategic Research Congress (s. 416-421). Celal Bayar University, Manisa, Turkey.

Aydoğan, E. (2015). Descartes'ın ahlak anlayışı [Descartes'sEthıcs]. Ataturk University, Journal of Faculty of Letters, 55, 101-115.

Azar, A. (2011). Türkiye'deki öğretmen eğitimi üzerine bir söylem: nitelik mi, nicelik mi? [Qualityorquantity: a statement for teachertraining in Turkey].Journal of Higher Education and Science, 1(1), 36-38. doi: $10.5961 /$ jhes. 2011.004

Baykara Pehlivan, K. (2008). Sınıf öğretmeni adaylarının sosyo-kültürel özellikleri ve öğretmenlik mesleğine yönelik tutumları üzerine bir çalışma [A study on the socio-cultural characteristics of classroom teacher candidates and their attitude stowards teaching profession]. Mersin University Journal of Faculty Education, 4(2), 151-168.

Baysal, S., \& Aka, Ç. İ. (2013). Bir pazarlama stratejisi olarak mutluluk temasının markalar tarafından kullanılması: mutluluk temelli pazarlama üzerine bir araştırma [The use of happiness as a marketing strategy by brands: a research on happiness-based marketing]. Journal of Social and Humanities, 5(1), 84-93.

Bohner, G., \& Wanke, M. (2002). Attitudes and attitudechange. Routledge: PsychologyPress.

Bulut, İ. (2009). Öğretmen adaylarının öğretmenlik mesleğine ilişkin tutumlarının değerlendirilmesi (Dicle ve Frrat Üniversitesi Örneği) [Evaluation of teacher candidates' attitudes towards teaching profession (Dicle and Frrat University Example)] . Dicle University Journal of Ziya Gökalp Faculty Education, 14(1), 13-24.

Bursalığlu, Z. 82012). Okul yönetiminde yeni yapı ve davranış (17. bs. [New structure and behavior in school management $\left(17^{\text {th }}\right.$ ed.)]. Ankara: Pegem Academy Publishing.

Büyüköztürk, Ş. (2015). Sosyal bilimler için istatistik (17. bs.) [Statistics for socialsciences (17 ${ }^{\text {th }}$ ed.)]. Ankara: Pegem Academy Publishing. 
Can, Ş. (2010). Tezsiz yüksek lisans öğrencilerinin mesleğine yönelik tutumları [Attitudes of non-thesis students towards their profession]. Muğla University Social Sciences Institute Review (24), 12-28.

Cevizci, A. (2003). Felsefe terimleri sözlüğ̈̈ [Dictionary of philosophical terms]. İstanbul: Paradigma Publishing.

Çelikten, M., Şanal, M. \& Yeni, Y. (2005). Öğretmenlik mesleği ve özellikleri [Teaching profession and its characteristics]. Erciyes University Journal of Social Sciences Institute, (19), 207-237.

Cihangir-Çankaya, Z. (2005). Öz belirleme modeli: Özerklik desteği, ihtiyaç doyumu ve iyi olma [Selfdetermination model: autonomysupport, needsatisfaction and goodness]. Doctorate Dissertation, Gazi University, Ankara, Turkey.

Çapa, Y., \& Çil, N. (2000). Öğretmen adaylarının öğretmenlik mesleğine yönelik tutumlarının farklı değişkenler açısından incelenmesi [Investigation of teacher candidates' attitudes towards teaching profession in terms of different variables]. Hacettepe University Journal of FacultyEducation, (16), 69-73.

Çiçek Sağlam, A. (2008). Müzik öğretmenliği bölümü öğrencilerinin öğretmenlik mesleğine yönelik tutumları [Attitudes of students of music teacher department towards teaching profession]. Yüzüncü Yll University Journal of FacultyEducation, 5(1), 56-69.

Demir, R. (2017). Öğretmen adaylarının mutluluk, iyimserlik, yaşam anlamı ve yaşam doyumlarının incelenmesi [Examination of teachercandidates' happiness, optimism, life meaning and life satisfaction]. Master Thesis, Gaziantep University,Institute of Educational Sciences, Gaziantep,Turkey.

Demirtaş, H., Cömert, M. \& Özer, N. (2011). Öğretmen adaylarının özyeterlik inançları ve öğretmenlik mesleğine ilişkin tutumları [Teachercandidates' self-efficacy beliefs and attitude stowards teaching profession]. Educational and Science, 36(159), 97-111.

Doğan, T., \& Çoban, A.E. (2009). Eğitim fakültesi öğrencilerinin öğretmenlik mesleğine yönelik tutumları ile kaygı düzeyleri arasındaki ilişkinin incelenmesi [Investigation of the relationship between attitudes of education faculty students towards teaching profession and anxiety levels]. Educational and Science, 34(153), 158-168.

Doğan, T., \& Çötok Akıncı, N. (2011). Oxford mutluluk ölçeği kısa formunun Türkçe uyarlaması:geçerlik ve güvenirlik çalışması [Turkish adaptation of the short form of Oxford happiness scale: validity and reliability study]. Turkish Psychological Counseling and Guidance Review, 4(36), 165-172.

Doğan, T. \& Sapmaz, F. (2012). Oxford mutluluk ölçeği Türkçe formunun psikometrik özelliklerinin üniversite ögrencilerinde incelenmesi [Examination of psychometricproperties of the Turkish version form of the Oxford happiness questionnaire in university students]. Thinking Man Journal of Psychiatry and Neurological Sciences, 25(4), 297-304.

Doğan, T., Sapmaz, F., \& Çötok Akıncı, N. (2013). Öz eleştiri ve mutluluk [Self-criticism and happiness]. Kastamonu Educational Review, 21(1), 391-400.

Duran, A. (2016). Okul yöneticilerinin mutluluk düzeylerinin öz yeterlilikleriyle ilişkisi (Amasya ili örneği) [Relation of the school managers' happiness levels to their self-sufficiency (Amasya province example)]. Master Thesis, Gaziosmanpaşa University, Institute of Educational Sciences, Tokat, Turkey.

Erdem, A., Gezer, K., \& Çokadar, H. (2005). Ortaöğretim fen-matematik ve sosyal alanlar öğretmenliği tezsiz yüksek lisans öğrencilerinin öğretmenlik mesleğine ilişkin tutumları [Attitudes of secondary school sciencemathematics and social science snon-thesis graduate students towards teaching profession]. 14th National Educational Science Congress Book, (s. 471-477). Ataturk University, Erzurum, Turkey. 
Erden, M. (1998). Öğretmenlik mesleğine giriş [Introduction to teaching profession]. İstanbul: Alkım Publishing.

Eryılmaz, A. (2011). Ergen öznel iyi oluşunun, öznel iyi oluşu arttırma stratejilerini kullanma ile yaşam amaçlarını belirleme açısından incelenmesi [Examination of ergative subjective well-being in terms of determining life goals by using subjective well-being enhancement strategies].Thinking Man Journal of Psychiatry and Neurological Sciences, 24(1), 44-51.

Franklin, S. S. (2010). The psychology of happiness. New York: Cambridge University Press.

Froom, E. (1995). Mutluluk ve erdem [Happiness and virtue]. (Ayda Yörükan, trans.) Ankara: T.İ.B.P.

Gönener, A., Öztürk, A. \& Yılmaz, O. (2017). Kocaeli üniversitesi spor bilimleri fakültesi öğrencilerinin mental (psikolojik) iyi olma düzeylerinin mutluluk düzeylerine etkisi [The effect of mental (psychological) wellbeing on the happiness levels of Kocaeli University sport science students]. SportiveSight: Journal of Sport and Education, 4(1), 44-55.

Gülcan, A. \& Nedim Bal, P. (2014). Genç yetişkinlerde iyimserliğin mutluluk ve yaşam doyumu üzerindeki etkisinin incelenmesi [Examining the effect of optimism on happiness and life satisfaction in young adults].Asian Teaching Review, 2(1), 41-52 .

Gürbüz, H., \& Kışoğlu, M. (2007). Tezsiz yüksek lisans programına devam eden fen edebiyat ve eğitim fakültesi öğrencilerinin öğretmenlik mesleğine yönelik tutumları (Atatürk Üniversitesi örneği) [Attitudes of the students of science literacy and education faculty towards the teaching profession (Atatürk University example)]. Erzincan Education Journal, 9(2), 71-83.

Habibzadeh,S. \& Allahvirdiyani, K. (2011). Effects of economic and noneconomicfactors on happiness on primaryschoolteachers and Urmia University professors. Procedia Social and Behavioral Sciences, 30, 20502051.

Hills, P., \& Argyle, M. (2002). The Oxford Happiness Questionnaire: A compactscale for the measurement of psychological well-being. Personality and Individual Differences, 33, 1073-1082.

Hybron, D. (2000). Two philosophical problems in the study of happiness. Journal of Happiness Studies, 1(1), 207-225.

Kangal, A. (2013). Mutluluk üzerine kavramsal bir değerlendirme ve Türk hane halkı için bazı sonuçlar [Aconceptual review on happiness and someconsequences for Turkish house hold]. Electronic Journal of Social Sciences, 12(44), 214-233.

Karasar, N. (2016). Bilimsel araşttrma yöntemi [Scientific research method]. İstanbul: Nobel Publishing.

Kaya, A. \& Büyükkasap, E. (2005). Physics student teachers' profiles, attitudes and anxiety toward teaching profession: An Erzurum sample. Kastamonu Education Journal, 13(2), 367-380.

Krech, D., \& Grutchfield, R. (1965). Sosyal psikoloji, (nazariyeler ve problemler) [Social psychology, (theories and problems)]. (Erol Güngör, trans.) İstanbul: Baha Press.

Küçükahmet, L. (2003). Öğretimi planlama ve değerlendirme [Planning and evaluation of teaching]. Ankara: Nobel Publishing Distribution.

Özder, H., Konedralı, G. \& Perkan Zeki, C. (2010). Öğretmen adaylarının öğretmenlik mesleğine yönelik tutumlarının çeşitli değişkenler açısından incelenmesi [Investigation of teacher candidates' attitudes towards teaching profession in terms of various variables]. Educational Administration: Theory and Practice, 16(2), 253-275. 
Özgen, M. K. (1997). Farabi'de mutluluk ve ahlak ilişkisi [Happiness and moral relation in Farabi]. İstanbul: Human Publications.

Russell, B. (2003). Mutluluk yolu [Happiness path]. (Nurettin Özyürek, trans.) İstanbul: Varlık Publications.

Ryan, R. M., \& Deci, E. L. (2001). On happiness and human potentials: a review of research on hedonic and eudaimonic well-being. AnnualReview of Psychology, 52(1), 141-166.

Semerci, N., \& Semerci, Ç. (2004). Türkiye'de öğretmenlik tutumları [Teacher attitudes in Turkey]. Furat University Journal of Social Science, 14(1), 137-146.

Şahin, F. S., Zade, B. M., \& Direk, H. (2009). Öğretmen adaylarının öğretmenlik mesleğine yönelik tutum ve yaşam doyum düzeyleri [Teacher candidates' attitudes towards the teaching profession and their level of life satisfaction]. XVIII. National Educational Sciences Congress. EgeUniversity, İzmir, Turkey.

Şenel, H. G., Demir, İ., Sertelin, Ç., Kılıçaslan, A., \& Köksal, A. (2004). Öğretmenlik mesleğine yönelik tutum ve kişilik özellikleri arasındaki ilişki [The relationship between attitudes and personality traits of the teaching profession]. Journal of Educational Researches (15), 99-109.

Şentürk, E. (2011). Mutluluk düzeyinin sosyo-demografik özelliklerle lojistik regrasyon analizi aracilı̆glyla incelenmesi ve Türkiye için bir uygulama [Through logistic regression analysis to examine the sociodemographic characteristics and level of happiness is an application for Turkey]. Master's Thesis, Marmara University, Institute of Social Sciences, İstanbul, Turkey.

Tarhan, N. (2013). Duyguların Psikolojisi [Psychology of feelings]. İstanbul: Timaş Publishing.

Temizkan, M. (2008). An evaluation on the attitudes of Turkish teacher an evaluation on the attitudes of Turkish Teacher Journal of Turkish Educational Sciences, 6(3), 461-486.

Tingaz, E. O. (2013). Beden eğitimi ve spor öğretmenliği ile bazı öğretmen adaylarının duygusal zekâ ve mutluluklarının karşılaştııılması [Comparison of physical education and sport teacher and emotional intelligence and happiness of some teacher candidates]. Master's Thesis, Gazi University, Institute of Educational Sciences, Ankara, Turkey.

Usta, E., \& Korkmaz, Ö. (2010). Öğretmen adaylarının bilgisayar yeterlikleri ve teknoloji kullanımına ilişkin algıları ile öğretmenlik mesleğine yönelik tutumları [Teacher candidates' perceptions about computer competencies and technology use and attitude stowards teaching profession]. International Journal of Human Sciences, 7(1), 1335-1348.

Veenhoven, R. (2000). Freedom and happiness: A ComparativeStudy in Fourty Four Nations in The Early 1990s. Cambridge: MIT Press.

Yalçın, R.Ü. (2016). Üniversite öğrencilerinin saldırganlık ve mutluluk düzeyleri arasındaki ilişkinin incelenmesi [Investigation of the relationship between university students' aggression and happiness levels]. Master's Thesis, Atatürk University, Institute of Educational Sciences, Erzurum, Turkey.

Yazıcı, Ö.F. (2015). Beden eğitimi öğretmeni adaylarının mutluluk ve zindelik düzeylerinin incelenmesi [Examination of the happiness and fitness levels of the physical education teacher candidates]. Master's Thesis, Karadeniz Technical University, Institute of Educational Sciences, Trabzon, Turkey. 